UDC 019.941:943.086.2

Submitted: 21.11.2017

LBC 63.3(4 Герм.)62-457

Accepted: 28.11.2017

\title{
Book Review: Havkin, B. L. German National Socialism and the Anti-Hitler Resistance [Text] / B. L. Havkin. - M. : Izd-vo KMK, 2017. - 377 p., 23 Applied Sheets
}

\author{
Nina E. Vashkau \\ Lipetsk State Pedagogical University, Lipetsk, Russian Federation
}

\begin{abstract}
This is a review of the monograph by B.L. Havkin, one of the leading scholars of the German antiHitler resistance during World War II. In his research the author presents a detailed analysis of the National Socialists, their origins and rise to power. He uses multiple sources that have recently become available in Russia and Germany. The Communist as well as the Conservative resistance is portrayed through the examples of the Ernst Thälmann and his Red Orchestra group, the priests and the soldiers, whose struggle against the Nazi-regime is highlighted with the help of the historical documents. Furthermore, the author describes how a pro-Soviet government was later created, as well as the National Committee for a Free Germany and the League of German officers, what role Walther von Seydlitz-Kurzbach and Friedrich Paulus played in these organizations. The research for this monograph is largely based on the formerly classified data from the archives of the Russian President, the Russian Federal Security Service, as well as the German Federal Archives. This newly released data helps the author illustrate the Conservative opposition to the Nazis and the 1944 assassination plot against Hitler organized by the German military personnel. B.L. Havkin also confirms Major Joachim Kuhn's participation in the assassination plot and describes his further contribution to the resistance movement. Additionally the monograph contains copies of rare photographs, leaflets, private letters, investigation protocols and other documents.
\end{abstract}

Key words: fascism, nazism, anti-Hitler resistance, World War II, Communist Party of Germany.

Citation. Vashkau N.E. Book Review: Havkin, B. L. German National Socialism and the Anti-Hitler Resistance [Text] / B. L. Havkin. - M. : Izd-vo KMK, 2017. - 377 p., 23 Applied Sheets. Vestnik Volgogradskogo gosudarstvennogo universiteta. Seriya 4, Istoriya. Regionovedenie. Mezhdunarodnye otnosheniya [Science Journal of Volgograd State University. History. Area Studies.International Relations], 2018, vol. 23, no. 1, pp. 206209. (in Russian). DOI: https://doi.org/10.15688/jvolsu4.2018.1.21

УДК 019.941:943.086.2

ББК 63.3(4 Герм.)62-457

Дата поступления статьи: 21.11.2017

Дата принятия статьи: 28.11.2017

\section{Рец. на кн.: Хавкин, Б. Л. Германский национал-социализм и антигитлеровское сопротивление [Текст] / Б. Л. Хавкин. - М. : Изд-во КМК, 2017. - 377 с., 23 вкл. л.}

\author{
Нина Эмильевна Вашкау \\ Липецкий государственный педагогический университет, г. Липецк, Российская Федерация
}

Аннотация. В рецензии анализируется монография одного из ведущих специалистов по истории сопротивления в Германии в период Второй мировой войны, доктора, профессора истории Бориса Хавкина.

Исследователь подробно рассматривает историю возникновения фашизма и нацизма, прослеживает путь нацистов к власти. Характеризуются комплексы источников, которые имеются сегодня в распоряжении исследователей двух стран. Рассматривает разные формы сопротивления - от коммунистического до консервативного. В движении Сопротивления участвовали самые разные личности и группы. В книге рассматривается 
роль Эрнста Тельмана и группы «Красная капелла»,судьба священников и военных, чья деятельность освещена на основе впервые вводимых в оборот архивных документов. Автор подробно рассматривает перспективу будущего антигитлеровского и просоветского правительства, анализирует документы национального комитета «Свободная Германия» и «Союз немецких офицеров», роль Ф. Паулюса и В. Фон Зайдлица в этом движении. Консервативная оппозиция и заговор против Гитлера в среде военных показаны с привлечением новых документов из Центрального архива ФСБ, в частности, восстанавливающие роль майора И. Куна в заговоре германских офицеров 20 июля 1944 г. против Гитлера. Особое внимание уделяется заговору и его влиянию на дальнейшее сопротивление. Монография основана на большом количестве новых источников из ранее засекреченных архивов Президента, ФСБ России, из архивов Германии (Bundesarchiv). В приложении помещены редкие фотографии, копии писем, листовок, протоколов допросов и другие документы.

Ключевые слова: фашизм, нацизм, антигитлеровское Сопротивление, Вторая мировая война, Коммунистическая партия Германии.

Цитирование. Вашкау Н. Э. Рец. на кн.: Хавкин, Б. Л. Германский национал-социализм и антигитлеровское сопротивление / Б. Л. Хавкин. - М. : Изд-во КМК, 2017. - 377 с., 23 вкл. л. // Вестник Волгоградского государственного университета. Серия 4, История. Регионоведение. Международные отношения. - 2018. T. 23, № 1. -C. 206-209. - DOI: https://doi.org/10.15688/jvolsu4.2018.1.21

Не часто можно обнаружить в серьезном научном труде посвящение своему учителю, но в этой книге я встречаю в первый раз посвящение сразу шести ученым, уже ушедшим из жизни, и составившим целую эпоху советской/российской германистики. Думаю, что эти имена должен знать каждый молодой исследователь, приступающий к интересной и многообещающей в смысле открытий и выводов истории российско-германских отношений. Известный историк-германист доктор исторических наук, профессор РГГУ Б.Л. Хавкин сделал очень правильно, посвятив свой обобщающий научный труд друзьям и коллегам: А.С. Бланку, Д.Е. Мельникову, Л.З. Копелеву, Л.А. Безыменскому, Я.С. Драбкину, А.И. Борозняку.

История национал-социализма и антигитлеровского сопротивления вызывает в российском обществе интерес с точки зрения написания правдивой истории Второй мировой войны и поиска ответа на вопрос: а были ли противники режима в самой Германии, или общество безмолствовало?

Из нескольких целей, поставленных автором перед собой, выделю некоторые: на примере истории немецкого антинацистского Сопротивления автором показан процесс «преодоления прошлого» в современном научном и общественно-политическом дискурсе Германии. Понадобилось более 40 лет, прежде чем германские историки переоценили роль и влияние антинацистской борьбы на послевоенное развитие Германии и всей Европы.
Прежде всего, подчеркну, что все разделы монографии базируются на значительном числе документов из фондов Архива Президента Российской Федерации; Государственного архива Российской Федерации; Российского государственного архива социальнополитической истории; Архива внешней политики МИД Российской Федерации; Российского государственного военного архива; Центрального архива ФСБ России; Архива Службы внешней разведки; Политического архива МИД ФРГ; Федерального архива во Фрайбурге; государственных архивов Ганновера, Гамбурга, Люцерна.

В движении Сопротивления участвовали самые разные личности и группы: от известного узника нацистских тюрем Эрнста Тельмана и группы «Красная капелла» до отдельных священников и военных, чья деятельность освещена в представленной книге на основе впервые вводимых в оборот архивных документов.

Автор начинает подробный анализ с коммунистического сопротивления, тематика которого господствовала в отечественной литературе. Он показывает многоаспектность антинацистской борьбы КПГ. В частности, показаны документальные разоблачения тайных гитлеровских вооружений, начиная с книги Эрнста Генри, первая из которых вышла в 1934 г. на английском языке. Перипетии с его псевдонимом и сама биография и сенсационный успех книг писателя хорошо прослеживаются.

Достойны упоминания новые факты из эпистолярного наследия Э. Тельмана. 24 письма за 1939-1941 гг., адресованные советско- 
му руководству и найденные в Архиве Президента РФ, были впервые опубликованы Хавкиным в 1996 г., и по-новому высвечивают позицию Тельмана в советско-германских отношениях. В письмах содержится просьба об освобождении из тюрьмы, но одновременно Тельман находит в себе силы для размышлений и анализа состояния международных отношений перед Второй мировой войной. Он советует Сталину присоединиться к лагерю «демократических стран» против Гитлера. Но его голос не был услышан. Он не получил помощи и был расстрелян по приказу Гиммлера 18 августа 1944 г. в концлагере Бухенвальд.

Принципиально важными являются страницы истории «Красной капеллы», в советской историографии базировавшиеся исключительно на иностранных источниках, теперь обнародованные следственные и реабилитационные дела участников организации. Весь комплекс открытых документов позволил поновому определить ее роль как организации немецкого антигитлеровского Сопротивления (c. 77), а не агентурной сети Москвы.

Организации немецкого сопротивления, известные как Национальный комитет «Свободная Германия» и «Союз немецких офицеров», имеют большую историографическую традицию. Следует подчеркнуть, что отход от наследия «холодной войны» позволил историкам ФРГ пересмотреть роль германского Сопротивления в истории войны. Это преодоление наследия прошлого далось нелегко.

Автор приводит только часть публикаций историков ГДР, ФРГ и СССР, в которых авторы противопоставляли друг другу участников консервативной оппозиции, заговора против Гитлера 20 июля 1944 г. и коммунистов и руководимых ими организаций (c.112-113). Но Б.Л. Хавкину важно подчеркнуть главное сходство: все организации боролись против Гитлера и отражали свое представление о послевоенном будущем Германии. Автор подробно рассматривает перспективу будущего антигитлеровского и просоветского правительства, анализирует манифест НКСГ, роль Ф. Паулюса и В. Фон Зайдлица в этом движении. Консервативная оппозиция и заговор против Гитлера в среде военных показаны с привлечением новых документов из Центрального архива ФСБ, в частности, восстанавливающие роль майора И. Куна - активного участника заговора германских офицеров против Гитлеpa (c. 214-230).

В книге восстанавливается подробно его биография и анализируются «собственноручные показания», данные им в качестве военнопленного и сохранившиеся в уголовном деле. На примере этой биографии автор демонстрирует филигранную источниковедческую работу, сопоставляя воспоминания Г. Айнзиделя, показания Куна, пояснительные записки офицеров СМЕРШа. Именно Кун снял по поручению К. фон Штауффенберга копии с программных документов заговорщиков. Покушение на Гитлера закончилось неудачей и казнью Штауффенберга и его сообщников. Но программа и внешнеполитические установки стали известны советскому руководству через несколько недель после 20 июля. Судьба Куна в советском плену сложилась трагически. После скитаний по тюрьмам, он был в 1956 г. репатриирован в ФРГ, где и скончался в 1994 г. всеми забытый, как явствует из переписки графа Г. фон Айнзиделя Б.Л. Хавкину от 9 января 2002 г. (с. 230). История Иоахима Куна - участника заговора против Гитлера и узника сталинских лагерей была неизвестна в России и замалчивалась в Германии. Поэтому возвращение памяти о нем - заслуга российского историка.

С большим интересом читается глава, посвященная конкретным биографиям участников антигитлеровского Сопротивления. Перед нами проходят портреты Вилли Лемана, Рудольфа Ресслера, графа Ф. Шуленбурга и др.

В целом надо еще раз подчеркнуть, что многочисленные документальные источники благодаря этой публикации стали доступными ученым и широкой аудитории. Особую ценность имеет включение корпуса источников личного происхождения - дневников и воспоминаний бывших немецких военнопленных участников движения «Свободная Германия», мемуаров советских разведчиков, опубликованных в 1990-е годы.

В приложении помещены редкие фотографии известных антифашистов, копии писем, листовок, протоколов допросов и другие редкие документы из рассекреченных фондов архивов России и Германии. Они позволяют представить героев повествования в разной 
Н.Э. Вашкау. Рец. на кн.: Хавкин, Б. Л. Германский национал-социализм и антигитлеровское Сопротивление

обстановке и расширить представление о драматических событиях.

Книга написана легко, с несомненным литературным даром. Она может быть рекомендована преподавателям университетов в качестве полноценного учебного пособия по спецкурсу. В ней присутствуют все необходимые атрибуты: внушительный список источников (извлеченных из российских и германс- ких архивов с подробным указанием фондов), обширная литература (российские и зарубежные публикации), именной указатель, который позволяет легко ориентироваться в тексте.

Таким образом, рецензируемая монография заметно обогатила историографию германского Сопротивления и будет интересна для специалистов по истории Германии и России.

\section{Information about the Author}

Nina E. Vashkau, Doctor of Sciences (History), Professor, Department of Russian and World History, Lipetsk State Pedagogical University, Lenina St., 42, 398040 Lipetsk, Russian Federation, vaschkau@mail.ru, https://orcid.org/0000-0001-9181-4381

\section{Информация об авторе}

Нина Эмильевна Вашкау, доктор исторических наук, профессор кафедры отечественной и всеобщей истории, Липецкий государственный педагогический университет им. П.П. Семенова-Тян-Шанского, ул. Ленина, 42, 398040 г. Липецк, Российская Федерация, vaschkau@mail.ru, https://orcid.org/0000-0001-9181-4381 